UNTAG Law Review (ULREV)

Volume 1, Issue 2, Nov 2017, PP 77-86

ISSN 2549-4910 (online) \& ISSN 2579-5279 (print)

http://jurnal.untagsmg.ac.id/indeks.php/ulrev/indeks

www.fakhukum.untagsmg.ac.id

\title{
IMPLEMENTATION OF CORPORATE SOCIAL RESPONSIBILITY IN SEMARANG CITY
}

\author{
Sigit Irianto \\ Lecturer at Faculty of Law UNTAG University Semarang \\ can contact by email sigitirianto70@gmail.com
}

\begin{abstract}
Research of social responsibility of companies in the city of Semarang is a research about the activities of the company as a partner of the Government and people in building the environment and the society. Implementation of corporate social responsibility attached to the values of the local wisdom. Article 74 of Act Number 40 of 2007 about Limited Liability Company and Government Regulation Number 47 Year 2012 about Social and Environmental Responsibility of Limited Liability Company has been set up corporate social responsibility as a part of the company's activities. The substance of corporate social responsibility is not only in the aspect of physical development, but also the empowerment of local communities. Semarang City Government has been managing corporate social responsibility with the funding through Gardu Kempling Program; this program isan Integrated Movement in Health, Economics, Education, Infrastructure, and Environment. Management of corporate social responsibility is used mostly to assist poverty reduction programs. The process of implementation of corporate social responsibility is accepted by the Semarang Regional Secretariat Cooperation Section. The company's understanding of the basis for the laws governing corporate social responsibility, most informants do not know the exact rules and regulations of governing the provision of corporate social responsibility. The focus of corporate social responsibility is to improve the quality of life until it finally emerged establishment communities to address social problems.
\end{abstract}

Key Words : Corporate Social Responsibility, Regulation, Implementation

\section{INTRODUCTION}

The corporate social responsibility has been a global issue recently, even it hasn't a single definition yet that globally accepted. Corporate social responsibility is the company's commitment which has a responsibility towards the consumers, employees, shareholders, community, and environment in all of the company's operational aspects. Corporate social responsibility closely linked to sustainable development, in order to improve the quality of human life and the beneficial environment, either for the company itself, the local community and society in general.

The values of local wisdom become an important part in the implementation of Corporate Social Responsibility, because each company cannot be separated from their social 
environment factors. The social environment affects the sustainable and development of existing companies. The embodiment of the values of local wisdom is highly varies, ranging from religious activities, social activities, and activities of other big celebrations.

The provisions in Article 74 of Act Number 40 Year 2007 about Limited Liability Company is very limited, either the limitation in article or the limitation in provisions because it only concerns for companies related to natural resources. However, the provisions on corporate social responsibility must be associated with a range of statutory provisions that exist, such as the Act on Environmental Management, Act on Investment, Employment Act, Act on StateOwned Enterprises, Act on Local Government, and others as well as Government Regulations governing corporate social responsibility primarily related to a Limited liability company which is Government Regulation Number 47 Year 2012 on Social and Environmental Responsibility of Limited Liability Company.

Various regulation is applicable to provide more clarity about the corporate social responsibility as a form of concern companies operating in Indonesia to all economic and social matters and the environment. Companies are no longer only emphasize the main goals in the field of business which is for profit as much as possible (profit oriented), but also must have concern for the social environment in the form of a concrete good. The main role of the company should be able to realize multipliers effect on the improvement of economic and social life in the company. Concern is also to avoid negative impacts from the company itself.

Lack of corporate social responsibility was a lot cause a tremendous impact on society. Case Tobapulp Lestari in North Sumatra, which was rumored to finish off the wood around the lake Toba which resulted in the lake is more shallow, controversial cases Buyat Bay in North Sulawesi, the issue of environmental pollution in the bay of Jakarta recently that resulted in fish from the waters of Jakarta infeasible in consumption, the issue of the failure of the harvest and the emergence of itching experienced by farmers and also slowly killing aquatic biota such as fish, gravestone and a conch in the villages Sukamulya Village Cilankap District of Babakan Cikao Purwakarta result fields splashed waste water originating in the area factory . Indo Bharat Rayon Company (rayon fiber company) and others. ${ }^{1}$

Phenomena of the cases above, all reveal the demands of moral responsibility and / or corporate social responsibility towards the environment of the operations of the community. Companies should not ignore the rights owned by the local community, such as the right to live a comfortable life is not disrupted and the right to a healthy life, ranging from clean water, clean air, away from the noise and others, and even the right to obtain a partnership in the field of business for small entrepreneurs and the right to draw the attention to the needs of others in the community.

The substance of corporate social responsibility is not only in the aspect of physical development, but how the company is able to empower local communities. Other context in corporate social responsibility is the sustainable responsibility. At the global order, slowly but surely the company whose products are related to exports and imports will be tied to ISO 26000 on corporate social responsibility whose implementation started at the end of 2009.

The research of implementation of corporate social responsibility was done in Semarang city. Semarang is a capital city of Central Java province and one of big city in Indonesia. Problem Statement

1 Tempo Magazine, No. 02/XXXIII/10 - $16^{\text {th }}$ of March 2003. 
1. How is the implementation of corporate social responsibility in Semarang City?

2. What obstacles are going to arise in the implementation of corporate social responsibility in Semarang City?

3. What are the goals to achieve corporate social responsibility in Semarang City?

\section{METHODS}

The research method was: the type of research was empiric juridical, with primary data as the main data which supported by secondary data. The research specification was analytic descriptive, for gave the detailed description, systematically, complete, factual and valid based on data correlation that had been done either by primary data or secondary data.

The data source was primary and secondary data. The data collecting method was done by interview for primary data and literature review for secondary data. Data then processed with: editing, coding, reconstructing, systematizing, and qualitatively analyzed.

\section{DISCUSSION}

\section{Implementation of Corporate Social Responsibility in Semarang City.}

Corporate social responsibility becomes inevitable demands along with the many demands of society against the company about its role in society. The debate in line with the demands of their Corporate Social Responsibility had appeared along with the neo liberalism that company has primary responsibility which is to look for profit as much as possible without regard to the interests of the surrounding community. However, the Company realized that its success in achieving the goal is not only influenced by internal factors but also by community hanging around. This means, there has been a shift in the relationship between companies and communities. Company that initially positioned itself as a charitable giving through charity activities and philanthropy is now positioned as a community of partners that contribute to the continued existence of the company. ${ }^{2}$

Results of research conducted on 69 medium and large companies / industries in Semarang City showed that most understand the corporate social responsibility. The level of understanding of the corporate social responsibility of each company is different, but the allocation of funds based on the profits earned.

Management and implementation of corporate social responsibility largely implemented with the involvement of universities in the city of Semarang. The involvement of universities shows the professionalism of the company in handling and implementing corporate social responsibility.

Semarang City Government has been managing corporate social responsibility with funding through Program Gardu Kempling, which is namely Integrated Movement in Health, Economics, Education, Infrastructure, and Environment. Management of corporate social responsibility is used mostly to assist poverty reduction programs. The process of implementation of corporate social responsibility is accepted by the Regional Secretariat Cooperation Section Semarang City, then the city administration in cooperation with universities both public and private sectors to implement the social responsibility of the company. Forms of corporate social responsibility activities are vary ranging from infrastructure development, health assistance, education assistance, capital support to the improvement of uninhabitable houses.

2 Rahman, Reza, 2009, Corporate Social Responsibility Between Theory and Realit, Media Pressindo, Yogyakarta, p 5. 
Management of corporate social responsibility which has existed largely used to helping poverty reduction programs. The process of implementation of corporate social responsibility has been received by a part of the cooperation the Regional Secretariat of Semarang. Furthermore the city government will cooperate with universities both public and private sectors to implement the corporate social responsibility. Forms of corporate social responsibility activities of are varying, ranging from infrastructure development, health assistance, education assistance, capital support to the improvement of uninhabitable houses. The amount of funds for the implementation of corporate social responsibility in 2011-2012 was US $\$ 4,275,351,000 ; 2000$, coupled with reading books and 3 units APE Outdoors, notebooks, and 10 sewing machines.

In the years 2012-2013 have been allocated funding of corporate social responsibility with a large enough amount of Rp 2,253,069,500; coupled with the Help Dhuafa and Scholarship, Free Treatment and Repair Facility IHC, repair 38 House No Livable, Medicine Mass, Checking Blood Sugar Free, cheapfood assistance, free groceries, infra structural development Selling hawkers in Simpanglima, Entrepreneurship Training, Development infrastructure bathing, washing and toilet General and three wheeled vehicles (Viar) in Sub Randusari Southern District of Semarang, and Making holes Biopori at 3 regions in the Village District of Ngaliyan Kalipancur.

In the years 2013-2014 have been allocated corporate social responsibility is accompanied by Rp 354.430.500 along with 3 wheeled vehicles, 3 Trash Carrier,6 Pedi cabs, 3 lawn mowers, 40 trash cans, 1300 tree seedlings.

The data above shows that the various companies in the city of Semarang mostly been doing corporate social responsibility. The Company is not limited to a particular industry or business, but any type of business or industry in the city of Semarang.

Most companies in Semarang conducting corporate social responsibility and similar activity to corporate social responsibility. Corporate social responsibility activities are generally carried out by large companies (corporations), while similar activities to corporate social responsibility were done by companies other than corporations.

Large companies (corporations, and banks), hotels, publishing companies, private radio, the finance company is a company which implements corporate social responsibility fund large enough to citizens. The amount of funds for the implementation of corporate social responsibility between Rp. 5 million - more than Rp. 5 billion / year.

\section{The Obstacles that Arise in Implementation of Corporate Social Responsibility in Semarang City.}

The notion of corporate social responsibility needs to be understood well by the company. As a form of corporate social accountability, they should allocate some of their profits. Many companies do not understand comprehensively about corporate social responsibility. Consequently many companies are not doing corporate social responsibility.

Results of the survey conducted on 69 companies / medium and large industries in Semarang showed that most understand about corporate social responsibility. The level of understanding of corporate social responsibility, each company was different. Most informants knew that many companies provide social assistance, but they did not know whether the assistance has included in the definition of Cooperate Social Responsibility or not.

Some companies claim that the provision was made because the existence and continuity of the company can't be separated from the surrounding community. The assistance was 
expected so the surrounding communities feel they have these companies so that they could participate in maintaining the existence of the company. Some informants from different companies said that the provision of corporate social responsibility or the aid is because of company policy, the company established a policy such assistance.

Data showed that the level of understanding of the informant as the company representative about corporate social responsibility was good, although normatively they did not know much for certain rules on corporate social responsibility. They claimed that the assistance was important and necessary for the company.

Almost all surveyed companies agreed with their corporate social responsibility. Surveyed informants stated that they agreed with the program of corporate social responsibility for corporate social responsibility is a form of corporate liability for their presence in the region. Based on the interview they stated that corporate social responsibility is a necessity in order that their business becomes smoother and more profitable.

The company's understanding of the basis for the laws governing corporate social responsibility, most informants do not know the exact rules and regulations governing the provision of corporate social responsibility. SOE Ministerial Decree number 236/2003 states that companies with a turnover of more than Rp. 1 billion are required to set aside $1 \%$ gain to a partnership or community development. The provisions of the SOE Ministry are not known by many informants interviewed. They merely provide assistance to communities that its amount and timing is uncertain.

Informant's answer on the understanding concluded that the level of understanding of the company's corporate social responsibility was not so good. Many informants do not understand the definition of corporate social responsibility and regulatory requirements concerning corporate social responsibility. They perform such an act of corporate social responsibility for the provision of assistance to local communities with corporate policy reason for the existence and continuity of their businesses secure and not disturbed by the surrounding community. Constraint in the company's understanding of corporate social responsibility is the lack of socialization of the government on the terms of corporate social responsibility. The company was not aware of any regulations from the government on corporate social responsibility obligations and provisions.

Most companies in Semarang conducted corporate social responsibility and similar activity of corporate social responsibility. Corporate social responsibility activities are generally carried out by large companies, while similar activities of corporate social responsibility were carried out by companies other than corporations. The table above shows that over $95 \%$ of companies in Semarang have conducted similar activities of corporate social responsibility in various forms. Among the forms of the activities, they were: social assistance (funds) to needy people, grant proposals, funding for the feast, food assistance and reforestation. Target of assistance was given to communities around the company and immediately given.

The image of the company will be increased and get a good response from the community, and the community helped with the activities of corporate social responsibility. Several corporations such as Telkomsel Company, BTPN Company, Bank Mandiri Company, Bank Syariah Mandiri Company and banking generally perform corporate social responsibility, taking into account the market the company concerned. The allocation of social grants as has been allocated a lot of companies, according to most informants said that social assistance has been provided to the public are still not able to overcome the problems that occur in the community. Assistance given to community was still in the form of charity, 
which will expire after consumption. Such assistance benefits only a moment and do not have a sustained impact for the improvement of community issues.

Community attitudes toward the existence of the company in general were good. A good response from the community was a manifestation of the company's attention to the environment (ring 1 company), the response which not good was because the company was less concerned about the environment and surrounding communities. Generally, this category is a type of medium-sized enterprises in the field of food or food - drink. This is due to the limited response of companies to the citizens and the environment. They still have ups and downs of business and do not have special funds for similar activities of corporate social responsibility.

Industry / company more concern in the social environment in the form of contributing to the needs of the surrounding community. This concern industry / company were less active even much far than proactive in looking at environmental issues which the industry / business was located. These conditions and supported by its own public behavior oriented on short-term needs will shape the views and attitudes that are less positive in developing the relationship between the environment and industrial / company with the community.

The company's attitude towards social issues, most companies passivity of the social and health problems. They help if they were requested by the public. Social problems such as poverty, health, education, especially in corporate environments and in Semarang in general, they paid little attention.

\section{Goal Achieve Corporate Social Responsibility in Semarang City}

Act Number 40 Year 2007 in Article 74 is imperatively asserts that corporate social responsibility is a legal obligation for companies that meet the criteria the Act set. Corporate social responsibility stipulated in the Company Act in 2007 was inspired by the recent growing view that taught the company as a company conducting the midst of people's lives, and then the company should take responsibility for the social problems faced by local communities.

Article 74 Act Number 40 Year 2007 is contentious because it creates the discriminatory impression. This discriminatory can be seen from the stipulation that only companies that move or relating to the natural resources that have corporate social responsibility. Therefore if we want to learn about the corporate social responsibility, we should seek harmonization with legislation to another. Another aspect that must be considered is the cultural and ethical aspects of society.

Each country has a different culture, for example in the United Kingdom tied with the code of conduct of business, in addition the company has realized the importance of corporate social responsibility to support the company's survival. The development of corporate social responsibility in the country has become so popular, so that corporate social responsibility is not only just as the demands of the company to the public and the environment, but corporate social responsibility is used as an indicator of performance evaluation of a company, even a company's social responsibility is used as requirements for companies wanting to go public. Those cultures have not happened in Indonesia, therefore it needs regulations to enforce corporate social responsibility. ${ }^{3}$

3 Constitutional Court, Verdict Number 53/PUU-VI/2008, Case Testing Application Law No. 40 Year 2007 on Limited Liability Companies towards the 1945 Constitution. On 15April 2009."Pertimbangan MahkamahmengenaikonstitusionalitasUndang-UndangNomor 40 tahun 2007 tentang Perseroan Terbatas p 91 
Many doubts about the importance of corporate social responsibility are still exist among companies. This occurs because of the view that a company's social responsibility programs that are not profitable so inevitably corporate social responsibility would be a burden and demands on the company alone. That requires a commitment by the government and companies to care and seek to actively provide concrete solutions on complex social issues in Indonesian society. Communities around the company can be friend and foe alike. Communities will be a friend if the company cared about, but it would be opposed if the company does not care about it. Losses would arise if there is a dissatisfaction of the community towards the company, the community can do anarchic action and it is not just about the comfort but also safety, as well as a great loss if it appears the anarchic action.

The focus of corporate social responsibility is to improve the quality of life until finally emerged the establishment communities to address social problems. The company is expected not only pursuing short-term profits, but participate and contribute to improving the welfare and quality of life and the environment in the long term.

Applicability of corporate social responsibility is not only to the provisions of the legislation and get sympathy from the public but this responsibility must also be sustainable and the needs of the company itself. The company will obtain the benefits of corporate social responsibility activities, namely:

1. Reducing the risk and the charges against inappropriate treatment received by the company. Companies that run consistently social responsibility will gain widespread support from the community who have benefited from the various activities undertaken. Corporate social responsibility will boost the positive image of the company in the long time span and will increase the company's reputation.

2. As a patron and help companies minimize the adverse effects caused by the crisis.

3. Involvement and pride for employees. Employees will feel proud to work for a company that has a good reputation, who consistently make the effort an attempt to help improve the welfare and quality of life of the community and environment. This pride will ultimately generate loyalty, so that they feel more motivated to work harder for the betterment of the company. This will lead to improvements in performance and productivity.

4. Able to improve and strengthen the relations between the company and stakeholders when corporate social responsibility implemented consistently. Implementation of corporate social responsibility which consistently show that firms have concern for the parties which have contributed to its current activities and progress achieved by the company.

5. Increased sales as expressed in Roper Starch Worldwide Research ${ }^{99}$, consumers will prefer products produced by companies that consistently perform its social responsibility so that it has a good reputation.

6. Other incentives such as tax and various other special treatments. It should be considered in order to encourage companies to more actively carry out its social responsibility.

The right goal implementation of corporate social responsibility will have an impact on improving the economy. Contribution for improving the economy of the community is divided into two directly or indirectly. Direct contribution is the contribution made by the company to set aside part of the profits for the benefit of the surrounding community. In addition to providing funding, the company's contribution can also be done by providing specific facilities, specific training and also lending either funds or facilities to the public. An 
indirect contribution is by the operation of a company, there will be a multiplier effect for the economy of surrounding communities. Economic activity surrounding communities increased in line with the needs of the workers of the company, the supply of goods to meet the needs and also the employment.

Corporate social responsibility is mandatory, so that arrangements can be made through local regulations. The obligation is also not imposed to all companies, but only limited to the company.

Implementation of the obligations of corporate social responsibility should budgeted by the company, meaning that corporate social responsibility was calculated as the cost of the company. This means that when the directors draw up the Annual Work Plan under Article 63 paragraph (1) of the Act Number 40 Year 2007, then it must contain corporate social responsibility budget for the financial year to come. Implementation of corporate social responsibility carried out with due regard to decency and fairness.

Companies that meet the criteria required to run the company's corporate social responsibility but did not perform its obligations, based on Article 74 paragraph (3) may be subjected to disciplinary action in accordance with the legislation in force. Sanctions against violations of companies that do not implement corporate social responsibility stipulated in the legislation related.

Companies are obliged to carry out corporate social responsibility in accordance with laws and regulations other than the Act Number 40 Year 2007 is not limited to the company whose main business is engaged in the field of natural resources or related to natural resources, but all companies that have met the criteria of the company or more forcefully companies which included a big effort required to run a corporate social responsibility.

\section{CONCLUSION}

1. Implementation of corporate social responsibility in Semarang is already running, although there is still no precise formulation yet. The companies allocate funds as a form of corporate social responsibility with magnitudes varied. In general, large companies have allocated funds for the implementation of social responsibility, while mid-sized companies in particular have not been allocated. Implementation of corporate social responsibility in generally carried out in collaboration with universities Semarang.

2. The obstacles that arise in the implementation of corporate social responsibility in Semarang, located in regulations that are not specifically and absence of regional regulations governing corporate social responsibility. The company leadership did not know exactly what is meant by corporate responsibility. Many doubts about the importance of corporate social responsibility still exist among companies. This occurs because of the view that a company's social responsibility programs that are not profitable so inevitably corporate social responsibility would be a burden and demands on the company alone.

3. Goal implementation of corporate social responsibility is not specifically aimed at certain areas, but in general for the benefit of people of Semarang. The target is improving quality of life until finally emerged establishment communities to address social problems. The target is not specifically addressed.

\section{SUGGESTION}

1. Require socializing with meet and dialogue between the parties with the communities 
where they operate. Follow-up of the meeting was the preparation of the priority areas of corporate social responsibility.

2. Legislation should be generally applicable, and must heed the foundations for the existence and strength. The third cornerstone is the philosophical grounding, grounding sociological and juridical basis. The third runway should be formulated together in a legislation to be drafted.

3. There should be a clear formulation that formulated by Semarang government regarding what areas to prioritize the implementation of corporate social responsibility. Priority will be followed up by companies to implement corporate social responsibility. Shape / form of corporate social responsibility, should be tailored to the interests of the community, especially around the company.

\section{REFERENCES}

Budimata, Arif,2008, Corporate Social Responsibility :Alternatifbagi Pembangunan Indonesia,ICSD, Jakarta.

Elkington, John, 2000, Cannibals With Forks : The Triple Bottom Line of $21^{\text {st }}$ Century Business, Journal of Business Ethics, Volume 23, Number 2, available from : http ://www.springerlink.com/business-and-economic.

Fuady, Munir , 2004, BisnisKotor : AnatomiKejahatanKerahPutih. Citra AdityaBakti, Bandung.

Handoyo, B. Hestu Cipto, 2008, Prinsip-prinsip Legal Drafting \& Desain Naskah Akademik, Universitas Atmajaya, Yogyakarta.

Hartono, Sri Redjeki, 2000, KapitaSelektaHukumEkonomi, MandarMaju, Bandung.

Khairandy, RidwandanCamilia Malik,2007, Good Corporate Governance: PerkembanganpemikirandanImplementasinya di Indonesia, Kreasi Total, Yogyakarta, 2007.

Mertokusumo, Sudikno, 1996, Bab-bab Tentang PenemuanHukum, Liberty, Yogyakarta.

Ndraha, Tadliziduhu, 2003, Kybernologi (ilmu-ilmu Pemerintahan Modern) 2, Rineka Cipta, Jakarta.

Rahardjo, Satjipto, 2006, Ilmu Hukum, Alumni, Bandung.

Rahman, Reza, 2009, Corporate Social Responsibility Antara Teori dan Kenyataan,Media Pressindo, Yogyakarta.

Setiawan,BoenHendra,2000, Bianglala Business Judgment Rule, Tatanusa, Jakarta.

Setiowati, Ardhy Pratiwi, 2009, Analisis Hubungan-Literatur, Fakultas Ekonomi Universitas Indonesia, Jakarta,

Siahaan,N.H.T. 2009, Environment Law, Pancuran Alam, Jakarta

SiswantoSutojo\& E. John Alridge, 2008, Good Corporate Governance PT. Damar Mulia Pustaka, Jakarta.

Solihin, Ismail,2009, Corporate Social Responsibility: from Charity to Sustainability, Salemba Empat, Jakarta.

Subekti, R., 1976, Aspek-aspekHukumPerikatanNasional, Alumni, Bandung. 
Suharto, Edi, 2009, Pekerjaan Sosial di Dunia Industri, Memperkuat Tanggung Jawab Sosial Perusahaan,Alfabeta, Bandung.

Van Dale, 2006, Groot Woordenboek der Nederlandse Taal, as quoted by Herlien Budiono, Het Evenwichtsbeginsel voor het Indonesisch Contractenrecht, Contractenrechtrecht op Indonesische Beginselen Geschoeid, Citra Aditya Bakti, Bandung, hlm. 304.

Wibisono, Yusuf, 2007, MembedahKonsepdanAplikasi Corporate Social Responsibility, Salemba Empat Jakarta.

Wijaya, Gunawan, dan Yeremia Ardi Pratama, 2008, Seri Pemahaman Perseroan Terbatas, Risiko Hukum \& Bisnis Perusahaan Tanpa Tanggung Jawab Sosial Perusahaan, Forum Sahabat, Jakarta.

\section{Legislations}

Constitution of the Republic of Indonesia Year 1945;

Act Number 12 Year 2011 on the Establishment of legislation;

Act Number 32 Year 2009 on the Protection and Environmental Management;

Act Number 20 Year 2008 on SMEs.

Act Number 40 Year 2007 regarding Limited Company;

Act Number 25 Year 2007 on Investment;

Act Number 13 on Employment

Act Number 19 Year 2003 on State Owned Enterprises;

Government Regulation No. 47 Year 2012 on Social and Environmental Responsibility Company Limited;

Journals, Papers, Court decision, Print Media, Electronic Media, Internet.

Kompas Newspaper, 23 April 2007.

Tempo Magazine No. 02/XXXIII/10 - 16 March 2003.

Warta Warga, Sunday Edition, 22 May 2011.

Warta Warga, Sunday Edition, 22 May 2011.

http://www.hupelita.com/baca.php?id=40253, accessed on 21 September 2013.

http://en.wordpress.com/tag/tugas-kuliah-corporate social responsibility, posted: 15September 2013.

Constitutional Court, Verdict Number 53/PUU-VI/2008, Case Testing Application Law No. 40 Year 2007 on Limited Liability Companies towards the 1945 Constitution. On 15April 2009."Pertimbangan Mahkamah mengenai konstitusionalitas UndangUndangNomor 40 tahun 2007 tetang Perseroan Terbatas". 